\title{
INSAN KAMIL DALAM PERSPEKTIF MUHAMMAD IQBAL
}

\author{
Rusdin \\ Insitut Agama Islam Negeri (IAIN) PALU
}

\begin{abstract}
Every being has individuality or self. Degree elevation on every being in nature depending on the level of development of each individuality. The criteria for determining the quality of every being is how far he can live up to himself effectively. Individuality is the distinguishing mark in the concept of Khudi or Iqbal ego. Iqbal's philosophy about Khudi ends on his thoughts about the insan kamil, the ideal man. Insan kamil is the highest level that can be achieved not by way of meditation, but with an original creative work, which is lawful overwhelmed by love or ishq, firmness self or faqr, courage and tolerance. Achieve this through three phases: obedience to God, self-control and the caliphate of God.
\end{abstract}

Keywords: Insan Kamil, Philosophy, Muhammad Iqbal, Concept

Setiap wujud mempunyai individualitas atau diri. Ketinggian derajat setiap wujud di alam ini tergantung pada tingkat perkembangan individualitasnya. Kriteria untuk menentukan kualitas setiap wujud adalah seberapa jauh ia dapat mengahayati dirinya secara efektif. Individualitas adalah tanda pembeda dalam konsep khudi atau ego Iqbal. Filsafat Iqbal tentang khudi ini bermuara pada 
pemikirannya tentang insan kamil, yaitu manusia ideal. Insan kamil merupakan taraf kedirian tertinggi yang dapat ditempuh tidak dengan cara meditasi melainkan dengan kerja kreatif yang orisinil, halal diliputi cinta atau ishq, keteguhan diri atau faqr, keberanian dan toleransi. Untuk mencapainya melalui tiga fase yaitu taat kepada Tuhan, pengendalian diri dan kekhalifahan Tuhan.

Kata Kunci: Insan Kamil, Filsafat, Muhammad Iqbal, Konsep

\section{PENDAHULUAN}

Muhammad Iqbal adalah setitik zarah di lautan semesta yang jiwanya senantiasa dalam keadaan resah. Jutaan manusia pelbagai bangsa pernah turut menyaksikan keresahannya di dalam ribuan bait syair yang ia tulis. Sosoknya memang fenomenal, lebih dari siapa pun, Iqbal telah merekonstruksi sebuah bangunan filsafat Islam yang dapat menjadi bekal individu muslim dalam mengantisipasi peradaban Barat yang materialistik ataupun tradisi Timur yang fatalistik. Jika diterapkan, maka konsep-konsep filosofis Iqbal akan memiliki implikasi kemanusiaan dan sosial yang luas. ${ }^{1}$ Filsafat Iqbal tentang khudi (diri) merupakan kunci untuk memahami seluruh sistem filsafatnya. Khudi adalah salah satu konsep dasar filsafat Iqbaldan merupakan alas penopang keseluruhan struktur pemikirannya. ${ }^{2}$ Pandangan Iqbal tentang khudi menjadi pintu gerbang bagi gagasannya tentang insan kamil, dan filsafat eksistensialisme ${ }^{3}$ merupakan landasannya.Sebagai satu cita ideal

\footnotetext{
${ }^{1}$ Doni Gahral Adian, Muhammad Iqbal(Bandung: Teraju, 2003), 23.

${ }^{2}$ Mustofa Anshori Lidinillah, Agama dan Aktualisasi Diri Perspektif Filsafat Muhammad Iqbal(Yogjakarta: Badan Penerbit Filsafat UGM, 2005), 55. Dikutip dari saiyidain" Progressive Trends in Iqbal Thought" (Lahore 1953), 23.

${ }^{3}$ Sqren Kierkegaard (1813-1855) berkebangsaan Denmark dan sebagai bapak eksistensialisme..Lihat I.R.Poedjawijatna, Pembimbing ke Arah Alam Filsafat(Jakarta:Rineka Cipta, 2005), 142.
} 
yang menjadi titik tuju dalam perjalanan kehidupan manusia, derajat insan kamilakan dapat diraih apabila ke-maujud-an diri diakui.

Insan kamil menurut Iqbaladalah bentuk manusia ideal, dan merupakan tingkat kedirian tertinggi yang mungkin dapat di capai oleh setiap diri. Insan kamil Iqbal dilatarbelakangi oleh kerinduan terhadap Tuhan serta tanggung jawab sebagai wakil (khalifah) Tuhan di bumi; dan menemukan bentuknya pada diri Rasulullah Muhammad SAW. ${ }^{4}$

\section{RIWAYAT HIDUP MUHAMMAD IQBAL}

Muhammad Iqbal dilahirkan di sebuah kota bernama Sialkot, Punjab (Pakistan Barat), sebuah kota peninggalan Dinasti Mughal India pada tanggal 3 Zulkaidah tahun $1294 \mathrm{H}$ bertepatan dengan 9 November 1877 M. ${ }^{5}$ Keluarga Iqbal berasal dari keluarga Brahmana Kashmir yang telah memluk agama Islam sejak tiga abad sebelum kelahiran Iqbal dan menjadi penganut agama Islam yang taat. Ayahandanya Syaikh Nur Muhammad memiliki kedekatan dengan kalangan Sufi. Karena kesalehan dan kecerdasannya, penjahit yang cukup berhasil ini dikenal memiliki perasaan mistis yang dalam serta rasa keingintahuan ilmiah yang tinggi. Tak heran, jika Nur

${ }^{4}$ Bagi Iqbal, Nabi Muhammad adalah segi aktivitas Tuhan yang dapat dilihat. Tuhan tidak dapat dilihat dengan mata manusia (al-Quran:7, 139), tetapi Nabi dapat dilihat dan diraba. Karena itu Iqbal berpaling kepada Nabi baik untuk memohon diberi kesembuhan maupun untuk memujinya, seperti yang terdapat dalam baris-baris sajak terakhirnya yang diterbitkan sesudah meninggalnya sebagai Armaghani-I Hijaz (Karunia Hijaz) Lihat: Annemarie Schimmel, "And Muhammad is His Messenger; The Venerationof the Prophet in Islamic Piety"terj. Rahmani Astuti dan Ilyas Hasan,Dan Muhammad adalah Utusan Allah ,Penghormatan terhadap Nabi SAW. Dalam Islam ,cet.Vlll (Bandung: Mizan, 2001), 320.

${ }^{5}$ Ahmad Mu'awwiḍ, Muhammad Iqbal Hayātihi wa atharihi (TT, 1980), 9. tahun kelahiran Iqbal terjadi perdebatan. Tahun disini mengacu pada informasi yang umum bahwa Iqbal meninggal 21 April 1938 dalam usia 60 tahun 
Muhammad dijuluki kawan-kawannya dengan sebutan "Sang Filosof tanpa guru" (un parh falsafi). ${ }^{6}$

Ibunda Iqbal, Imam Bibi, juga dikenal sangat relegius. Ia membekali kelima anaknya, tiga putri dan dua putra, dengan pendidikan dasar dan disiplin keislaman yang kuat. Di bawah bimbingan kedua orangtuanya yang taat inilah Iqbal tumbuh dan dibesarkan. Kelak di kemudian hari, Iqbal sering berkata bahwa pandangan dunianya tidaklah dibangun melalui spekulasi filosofis, tetapi diwarisi dari kedua orangtuanya tersebut.Pendidikan dasar sampai tingkat menengah ia selesaikan di Sialkot. Pada masa yang sama ia mendapatkan pendidikan agama secara langsung dari seorang guru yang ahli bahasa Arab dan Persia yang bernama Mir Hasan, dari guru beliau inilah ia memahami Islam secara mendalam, mengajarinya sikap kritis dan mengasah bakatnya dalam dunia kesusasteraan. ${ }^{7}$ Pada tahun 1895 ia pergi ke Lahore, salah satu kota di India yang menjadi pusat kebudayaan, pengetahuan dan seni. Di kota ini ia bergabung dengan perhimpunan sastrawan yang sering diundang mushara'ah, yakni pertemuan-pertemuan di mana para penyair membacakan sajak-sajaknya.

Ini merupakan tradisi yang masih berkembang di Pakistan dan India hingga kini. Di kota Lahore ini, sambil melanjutkan pendidikan sarjananya ia mengajar filsafat di Government College. Pada tahun 1897 Iqbal memperoleh gelar B.A., kemudian ia mengambil program M.A. dalam bidang filsafat. Pada saat itulah ia bertemu dengan Sir Thomas Arnold, orientalis Inggris yang terkenal, yang mengajarkan filsafat Islam di College tersebut.

6 http://dutabengkalis.blogspot.com/2008/06/dr-muhammad-iqbal.html. Lihat Hary Hasyimsyah Nasution, Filsafat Islam (Jakarta: Gaya Media Pratama, 1999), 24.

${ }^{7}$ http://id.wikipedia.org/wiki/Muhammad Iqbal 
Selama pendidikan ini Iqbal menerima beasiswa dan dua mendali emas karena prestasinya dalam bahasa Arab dan bahasa Inggris. Ia akhirnya memperoleh gelar M.A pada tahun $1899 .{ }^{8}$

Dengan dorongan dan dukungan dari Arnold, Iqbal menjadi terkenal sebagai salah satu pengajar yang berbakat dan penyair di Lahore. Sajak-sajaknya banyak diminati orang. Pada tahun 1905, ia belajar ke Eropa untuk melanjutkan studi di Trinity College diUniversitas Cambridge London sambil ikut kursus advokasi di lincoln Inn. Dilembaga ini ia banyak belajar pada seorang NeoHegelian, yaitu Jhon M.E.McTaggart. Iqbal kemudian belajar di Heidelberg dan terakhir di Munich. ${ }^{9}$ Di Munich ia menyelesaikan doktornya pada tahun 1908 dengan disertasi, The Development of Metaphysics in Persia.(disertasi ini kemudian diterbitkan di London dalam bentuk buku, dan dihadiahkan Iqbal kepada gurunya, Sir Thomas Arnold). Setelah mendapatkan gelar doktor, ia kembali ke London untuk belajar di bidang keadvokatan sambil mengajar bahasa dan kesusastraan Arab di Universitas London, Iqbal juga masuk di School of Political Sains untuk beberapa lama.

Selama di Eropa Iqbal tidak pernah bosan menemui para ilmuwan untuk mengadakan berbagai perbincangan tentang persoalan-persoalan keilmuan dan kefilsafatan. Ia juga memperbincangkan Islam dan peradabannya. Di samping itu Iqbal memberikan ceramah dalam berbagai kesempatan tentang Islam. Isi ceramahnya tersebut dipublikasikan dalam berbagai penerbitan surat kabar. Setelah menyaksikan langsung dan mengkaji kebudayaan Barat, ternyata ia tidak terpesona oleh gemerlapan dan daya pikat kebudayaan tersebut. Iqbal tetap concern pada budaya dan kepercayaannya. Namun semua itu tidak lama karena Iqbal lebih

\footnotetext{
${ }^{8}$ Mukti Ali, Alam Pikiran Islam Modern di India dan Pakistan (Bandung: Mizan,1993), 174.

${ }^{9}$ Robert D.Lee, Mencari Islam Autentik dari nalar puitis Iqbal hingga nalar kritis Arkoun (Bandung: mizan, 2000), 70.
} 
memilih pulang ke Lahore, dan membuka praktek pengacara di samping sebagai guru besar di Goverment College Lahore. Akan tetapi panggilan jiwa seninya yang kuat membuat ia keluar dari profesi tersebut. Ia juga menolak ketika ditawari sebagai guru besar sejarah oleh Universitas Aligarh tahun 1909. Iqbal lebih memilih sebagai penyair yang kemudian mengantarkannya ke puncak popularitas sebagai seorang pemikir yang mendambakan kebangkitan dunia Islam, yang kemudian juga menyampaikannya untuk mendapatkan gelar Sir (kebangsaan) dari pemerintah, sekitar tahun $1922 .^{10}$

Akhir tahun 1926, Iqbal mulai masuk kehidupan politik ketika dipilih menjadi anggota DPR Punjab. Bahkan, tahun 1930, ia di tunjuk sebagai Presiden sidang tahunan Liga Muslim yang berlangsung di Allahabad, yang menelorkan gagasan untuk mendirikan Negara Pakistan sebagai alternatif atas persoalan antara masyarakat Muslim dan Hindu. ${ }^{11}$ Meski mendapat reaksi keras dari para politisi, gagasan tersebut segera mendapat dukungan dari berbagai kalangan, sehingga Iqbal diundang untuk menghadiri konferensi meja bundar di London tahun 1932, juga konferensi yang sama pada tahun berikutnya, guna membicarakan lebih lanjut tentang gagasan tersebut. Iqbal terus berkarya dan membangkitkan semangat jiwa bangsanya pada tahun 1935 ia di angkat sebagai

${ }^{10}$ A. Khudori Soleh, Wacana Baru Filsafat Islam(Yogyakarta: pustaka belajar, 2004), 302. Lihat Abdul Wahab azam, Muhammad Iqbal Siratuhu wa Falsafatuhu wa Sha'ruhu, terj. Rafik Usman, Filsafat dan Puisi Iqbal (Jakarta: pustaka, 1985), 37-38.

${ }^{11}$ Dalam sebuah pidato Iqbal mengemukakan gagasan tentang sebuah Negara Islam di India, namun cita-cita Iqbal baru terwujud pada tahun 1947 tanpa Iqbal dapat menyaksikannya.Sebagaimana juga diungkapkan oleh Quaid -IAzam"Walau Iqbal tidak lagi bersama kita, tetapi kalau dia masih hidup dia akan bahagia mengetahui kita melakukan apa yang diinginkan.Lihat; Asif Iqbal Khan, “Some Aspects of Iqbal Thought”.Terj. Farida Arini, Agama, Filsafat, Seni dalam Pemikiran Iqbal(Yogyakarta: Fajar Pustaka Baru, 2002), 147. 
ketua Liga Muslim cabang Punjab. Iqbal, baik sebagai pujangga, filosof, politikus, ahli pendididkan dan ahli bidang hukum adalah pribadi yang produktif hingga akhir hayatnya. Ketika tinggal di Bhopal pada tahun 1936, ia menderita sakit yang sangat serius ${ }^{12}$, dan akhirnya wafat pada tanggal 21 april $1938 .{ }^{13}$

Adapun karya-karya Iqbal sebagai berikut:

1. Karya yang berbahasa Persia Asrar-i- Khudi(rahasia pribadi, 1915), Rumuz-i bukhudi(rahasia tidak mementingkan diri sendiri, 1918), Payam-i-Masriq(pesan dari timur, 1923), Zaburi-i- Ajam, Javid Namah(1932), Pasceh Baid Aye Aqwam-i-Syarq dan Lala-i-Thur.

2. Yang berbahasa Urdu : Ilmu Al-Iqtisad (ilmu ekonomi), Bangi-Dara(seruan dari perjalanan, 1924), Bal-i- Jibril(1938), Zarbi-Kalim, Arughan-i-Hijaz, Iblis ki Majlis-i-Syura, Iqbal Namas, Makatib Iqbaldan Bagiyat-i-Iqbal.

3. Yang berbahasa Inggris : Develoment of Methaphysies in Persia: A Contribution to the history of Moslem, Philoshopy (perkembangan metafisika Persia suatu sumbangan untuk sejarah filsafat Islam) dan the Reconstroction of Religius Thought in Islam (pengembangan kembali alam pikiran Islam). ${ }^{14}$

Filosof-filosof Barat yang banyak mempengaruhi pemikiran Iqbal diantaranya Nietzsche, Bergson, dan Nietzsche (1844-1900 M) adalah filsuf Jerman yang terkenal dengan ajarannya tentang ubermensch ${ }^{15}$ Bergson (1859-1941)adalah filsuf Perancis yang

\footnotetext{
${ }^{12}$ Annmarie Schimmel, Dan Muhammad adalah utusan Allah ....,319.

${ }^{13}$ Robert D.Lee, Mencari Islam Autentik dari Nalar Puitis Iqbal hingga Nalar Kritis Arkoun, 72.

${ }^{14} \mathrm{http}: / /$ dutabengkalis.blogspot.com/2008/06/dr-muhammad-iqbal.html.

${ }^{15}$ Ubermensch adalah konsepsi tentang bentuk manusia unggul yang dicapai dengan kerja keras yang didasari keyakinan tentang kematian Tuhan. Lihat Donny Gahral Adian, Muhammad Iqbal (Bandung: teraju,2003), 34.
} 
terkenal dengan ajarannya tentang elan vital $^{16}$.Sedangkan seorang Sufi yang mempunyai pengaruh mendalam terhadap Iqbal adalah Maulana Jalalludin Rumi (1217-1273 M), Iqbal mencontoh cara Rumi bersajak. Matsnawi atau sajak panjang Iqbal adalah seperti bentuk sajak Rumi, bahkan terdapat kesamaan semangat pemikiran antara Iqbal dan Rumi.

\section{FILSAFAT KHUDI}

1. Pengertian Khudi

Gagasan tentang khudi dalam filsafat Islam modern merupakan konsep dasar dalam filsafat Iqbal dan sepenuhnya adalah milik Iqbal. Menurut Sardar Jefri gagasan tentang Khudi ini merupakan sumbangan Iqbal terbesar...yang melukiskan manusia sebagai penerus ciptaan Tuhan yang mencoba membuat dunia yang belum sempurna menjadi sempurna. ${ }^{17}$ Masalah ini dibahas dalam karyanya yang ditulis dalam bahasa Persia dengan bentuk matsnawi berjudul Asrar-i Khudi; kemudian dikembangkan dalam berbagai puisi dan kumpulan ceramah yang selanjutnya dibukukan dengan judul The Reconstruction of Relegious Thought in Islam.

Khudi adalah perkataan bahasa Persi, bentuk kecil dari kata khuda yang berarti Tuhan; sedangkan secara harfiyah khudi berarti kedirian (selfhood) ${ }^{18}$ yang biasa juga diterjemahkan sebagai ego, diri,

${ }^{16}$ Hamersma, Tokoh-tokoh Filsafat Barat Modern (Jakarta: PT. Gramedia, 1984),103. Bergson berpendapat alam raya adalah evolusi kreatif. Seluruh proses evolusi sebagai usaha elan vital untuk membebaskan diri dari deteminasi materi.

${ }^{17}$ M.Dawam Rahardjo, Insan Kamil, KonsepsiManusia Menurut Islam (Jakarta: Pustaka Grafitipers, 1987), 16. Dikutip dari Ali Sardar Jafri dan K.S.Duggal, Commerorative Volume (New Delhi: All Indian Iqbal Centenary Celebration Committee, 1977), 12-13.

${ }^{18}$ Rahardjo, Insan Kamil....,17. Lihat Sh. Abdul Qadir, Iqbal The Great Poet of Islam (Lahore: Sang e Meel Publication, 1975), 116. Lihat juga Muhammad Iqbal, "Asrar -I Khudi”, terj. Bahrum Rangkuti, Rahasia-Rahasia Pribadi (Jakarta: Pustaka Islam,tth), 13. 
Rusdin, Insan Kamil dalam Perspektif Muhammad Iqbal...259

pribadi atau invidualitas. Khudi merupakan pusat landasan organisasi kehidupan manusia. ${ }^{19}$ Iqbal dalam makalahnya, seperti yang dikutip oleh Abdul Wahhab Azzam dan diterjemahkan ke dalam bahasa Indonesia oleh Ahmad Rofi' Usman, tentang khudi menerangkan;

"kesatuan intuitif atau titik kesadaran pencerah yang menerangi pikiran, perasaan dan keinginan manusia, merupakan hal yang diliputi rahasia dan mengorganisasi berbagai kemampuan yang tidak terbatas dalam fitrah manusia. Hal ini yang kita sebut khudi atau aku atau mind, tampak dalam tindakan-tindakan namun tidak tampak dalam realitas. Pusat kehidupan manusia adalah pribadi (khudi) atau person. Maksud saya bahwa kehidupan pada waktu ia tertampilkan dalam diri manusia, ia disebut pribadi" ${ }^{20}$

Iqbal menerangkan bahwa khudi merupakan pusat dan landasan dari keseluruhan kehidupan. Hal ini tercantum pada beberapa matsnawinya dalam Asrar-i Khudi.

Bentuk kejadian ialah akibat dari khudi

Apa saja yang kaulihat ialah rahasia khudi

Dijelmakannya alam cinta dan pikian murni

Apa guna wujudmu melainkan untuk mengembangkan dayamu?

Kalau kau perkuat dirimu dengan khudi

Kau akan pecahkan dunia sesuka khudimu;

Jika kau hendak hidup, isilah dirimu dengan khudi

Apakah mati sebenarnya? Melepaskan semua khudi

Kenapa berkhayal itulah terpisahnya roh dari tubuh

Bermukimlah dalam khudi, penaka Yusuf

Majulah dari rebutan yang satu ke rebutan yang lain

${ }^{19}$ K.G. Saiyidain, "Iqbal Education Filosofi" Percikan Filsafat Iqbal tentang Pendidikan, terj: MI sulaiman (Bandung CV. Diponegoro, 1981), 24.

${ }^{20}$ Abdul Wahhab Azzam, Filsafat dan Puisi Iqbal, 45 dan 52. 


\section{Pikirkanlah khudimu dan jadilah beraksi}

Jadilah manusia-Tuhan, kandunglah rahasia dalammu".21

Ketika mempelajari arti ego (Khudi), Iqbal membedakan artinya secara metafisika dan secara etika. Secara metafisika kata ego digunakan untuk menggambarkan perasaan yang tidak terdefinisikan dalam "aku"yang membentuk dasar keunikan dari setiap individu. Secara etika kata ego berarti (yang saya gunakan) percaya pada diri sendiri, harga diri, mandiri, penyelamatan diri sendiri, keyakinan diri, bahkan penegasan diri. Ego dalam pengertian etika inilah yang akan mengarah pada konsep tentang insan kamil, karena menurut Iqbal realisasi diri akan memperbaiki pribadi manusia dan membantunya meraih kebesaran anugerah Tuhan. $^{22}$

Filsafat Iqbal tentang khudi merupakan kritik dan sekaligus koreksi terhadap pandangan dan sikap yang kurang memperhatikan pentingnya individualitas. Individualitas adalah tanda pembeda dalam konsep ide Iqbal. Iqbal percaya kalau perkembangan individualitas tidak hanya memastikan kebebasan bagi ego manusia tetapi juga memberikan kehidupan yang abadi. ${ }^{23}$ Iqbal, dengan berpedoman pada al- Qur'an, berhasrat meluruskan pandangan dan sikap tersebut. Iqbal berpendapat, al- Qur'an dengan cara yang sederhana namun tegas menekankan individualitas dan keunikan manusia serta nasib manusia sebagai satu kesatuan hidup. Masalah itu, ironisnya, tidak pernah menjadi titik perhatian dalam sejarah pemikiran muslim. $^{24}$

Terdapat dua bentuk ketidak pedulian manusia terhadap individualitas yang hendak di luruskan oleh Iqbal melalui

\footnotetext{
${ }^{21}$ Muhammad Iqbal, Rahasia-Rahasia Pribadi, 93.

${ }^{22}$ Asif Iqbal Khan, Agama, Filsafat, Seni Dalam Pemikiran Iqbal, terj. Farida Arini (Yogyakarta: fajar pustaka baru, 2002), 41.

${ }^{23}$ Khan, Agama, Filsafat ....., 46.

${ }^{24}$ Muhammad Iqbal, The Reconstruction of Religious Thought In Islam (Lahore:institute of Islamic culture, 1986), 95.
} 
pemikirannya tentang khudi. Pertama, ketidak pedulian manusia terhadap individualitas yang tercermin dalam sikap hidup memandang dunia ini bukan merupakan realita tetapi hanya bayangan saja. Akibatnya, manusia kurang memperhatikan aspek kehidupan duniawi. Sikap seperti itu banyak dijumpai di dunia Timur dan juga di dunia islam terutama pada masa Iqbal hidup.

Kedua, ketidak pedulian manusia terhadap individualitas yang tercermin dalam sikap hidup mengagungkan materi secara berlebihan. Sikap hidup seperti itu mengakibatkan diri manusia menjadi budak benda-benda material, dan karenanya nilai kemanusiaannya tidak lebih berharga dari pada benda-benda material yang di agung-agungkan. Sikap hidup seperti itu, pada masa Iqbal, banyak dijumpai di dunia Barat, yang peradabannya bertumpu pada filsafat materialisme dan rasionalisme.

Iqbal berpendapat, setiap wujud mempunyai individualitas atau diri, ketinggian derajat setiap wujud di alam ini tergantung pada tingkat perkembangan individualitasnya. Tingkat-tingkat keadaan dari setiap wujud pada dasarnya juga merupakan derajatderajat dari individualitas atau diri. Kriteria untuk menentukan kualitas dari setiap wujud ialah seberapa jauh ia dapat menghayati dirinya secara mantap. Iqbal seorang humanis yang percaya kepada kemampuan manusia untuk berkembang dan mencapai tingkat kedirian yang tinggi. Iqbal lebih cenderung menggunakan istilah khudi untuk menyebut diri manusia.

\section{Karakteristik Khudi}

a. Khudi bersifat tersendiri dan unik

Iqbal berpendapat, hidup adalah diri, hakikat diri walaupun berinteraksi dengan diri-diri lain, namun ia tetap terpusat pada dirinya sendiri dan memiliki lingkup kedirian sendiri, lepas dari diridiri lain di luar dirinya. Khudinampak semakin unik pada taraf yang lebih tinggi. Khudi pada manusia, nampak semakin unik dibandingkan dengan organism lain. Iqbal berpendapat Al Qur'an menekankan individualitas dan keunikan manusia. Seorang manusia 
tidak akan menanggung beban orang lain, seorang manusia hanya akan mendapatkan apa yang diusahakan.

b. Khudi tidak terikat ruang dan waktu

Ruang yang dimaksud adalah ruang sebagaimana raga terikat di dalamnya. Khudi tidak terikat ruang, ketika raga saya berada dalam suatu ruang, saya dapat menembus ruangan itu dengan membayangkan atau memikirkan ruangan yang lain. Kata Iqbal: "Indeed the ego can think of more than one space order" ${ }^{25}$ Khudi juga tidak terikat oleh waktu. Kekinian diri saya merangkum juga di dalamnya masa lalu dan masa depan. Masa lalu dan masa depan ini kemudian turut juga menjadi pertimbangan bagi terwujudnya tindakan fisik dalam kekinian diri saya. Iqbal berpendapat, jangka waktu dari diri itu berbeda dengan jangka waktu dari peristiwa fisik. Jangka lama dari peristiwa terbentang dalam ruangan sebagai satu kenyataan masa kini; jangka lama dari peristiwa terpusat di dalamnya dan terpaut antara masa lalu, masa kini, dan masa depan dengan cara yang unik.

\section{c. Khudi itu bertaraf}

Ada khudi yang lebih rendah dan ada khudi yang lebih tinggi. Tinggi rendahnya taraf khudi setiap wujud tergantung pada tingkat kemampuan menghayati diri secara mantap. Khudi yang tingkatnya lebih rendah terdapat pada materi atau benda fisik. Khudi yang tingkatnya paling tinggi terdapat pada manusia. Sedang khudi yang paling sempurna adalah diri Tuhan. Khudi manusia itu juga bertaraf. Pendapat Iqbal ini diperkuat dengan mengutip alQur' an surat al-Inshiqaq (84) ayat 19: "Sesungguhnya kamu melalui tingkat demi tingkat dalam kehidupan".

d. Khudi bersifat dinamis

Khudi dapat menjadi semakin kuat dan dapat menjadi lemah. khudi menjadi semakin kuat apabila semakin tebal rasa keakuannya sebagai diri yang berpusat pada dirinya sendiri. Khudi menjadi

${ }^{25}$ Muhammad Iqbal, The Reconstruction of Religious Thought In Islam, h. 99 
semakin lemah bila rasa keakuan sebagai diri yang berpusat pada dirinya sendiri tipis atau kurang. Keadaan semakin kuat dan juga melemahnya khudi di alami oleh manusia yang telah mencapai tingkat yang relative tinggi dalam perkembangan khudi.

Menguat dan melemahnya khudi dipengaruhi oleh faktorfaktor tertentu. Iqbal menyebutkan faktor-faktor yang memperkuat khudi, yaitu: adanya cinta kasih, sikap faqr, sikap berani atau keberanian, toleransi, kasb-I halal, kerja kreatif dan asli. Sedangkan melemahkan khudi: sikap penakut, sikap meminta-minta, perbudakan, dan sikap sombong. ${ }^{26}$

e. Khudi itu bersifat teleologis

Ketidak terikatan khudi oleh ruangan dan waktu berakibat khudi dapat membayangkan atau memikirkan keadaan atau masa depan yang lebih baik dari keadaan sekarang. Diri manusia sebenarnya lebih dari dirinya yang sekarang, meskipun ia belum menjadi wujudnya yang akan datang. Tingkat-tingkat khudi bukanlah barang jadi, melainkan suatu hasil pencapaian. ${ }^{27}$ Setiap wujud berjuang untuk mencapai tingkat kedirian yang lebih tinggi atau sempurna. Tingkat kedirian yang lebih tinggi dan sempurna tidak hanya dicita-citakan oleh manusia saja, tetapi juga oleh setiap wujud atau setiap organism. Akan tetapi dari keseluruhan wujud atau organisme, manusia sajalah yang berhasil mencapai tingkat kedirianyang relatif tinggi dan sempurna.

Iqbal berpendapat, mengembangkan diri untuk mencapai tingkat kedirian yang lebih tinggi dan sempurna berarti bergerak mendekati Tuhan. Tuhanlah satu-satunya diri yang paling tinggi dan sempurna. Upaya untuk mendekati Tuhan, pada manusia, tidak pernah berhenti pada suatu titik atau keadaan tertentu. Kematian raga, tidak berarti diri manusia juga mati. Kematian raga adalah satu fase dari kehidupan diri manusia. Diri manusia, melalui kematian

${ }^{26}$ Muhammad Iqbal, Rahasia-Rahasia Pribadi, h. 30

${ }^{27}$ Ahmad Safi'I Ma'arif dan Muhammad di Ponegoro, Percik-Percik Pemikiran Iqbal(Yogyakarta: salahuddin press, 1983), 28. 
raga, akan melihat bagi dirinya akibat-akibat amalnya di masa lampau dan menghakimkan kemungkinan-kemungkinan bagi masa depan.

Iqbal dengan filsafat khudi-nya sebenarnya telah membentangkan sebuah rencana yang matang bagi upaya aktualisasi diri manusia. Iqbal menunjukkan bahwa diri manusia menyimpan potensi tak terbatas dan memiliki berbagai kemungkinan bagi aktualisasinya.

\section{INSAN KAMIL PERSPEKTIF MUHAMMAD IQBAL}

1. Insan kamil puncak aktualisasi diri

Pemikiran Iqbalmengenai khudi bermuara pada pemikirannya tentang insan kamil. Insan kamil adalah taraf atau derajat tertinggi yang dapat dicapai oleh khudi dalam perkembangannya. Insan kamil merupakan bentuk manusia yang ideal, manusia yang benar-benar sempurna sebagai manusia. Tema tentang manusia ideal menjadi pembahasan banyak pemikir. Tiap-tiap pemikir mempunyai konsep yang berbeda tentang bentuk manusia ideal. Abdul karim bin Ibrahim al-Jili(1365-1428), seseorang mistikus, berpendapat bahwa manusia ideal merupakan gambaran Tuhan, dan dalam kenyataannya, manusia adalah rantai yang menyatukan Tuhan dengan alam semesta. Insan kamil artinya manusia sempurna, berasal dari kata al-insan yang berarti manusia dan al-kamil yang berarti sempurna. Konsepsi filosofis ini pertama kali muncul dari gagasan tokoh sufi Ibnu Arabi $^{28}{ }^{28}$ menurutnya insan kamil adalah mikrokosmos yang sesungguhnya, sebab dia memanifestasikan semua sifat dan kesempurnaan Ilahi, dan manifestasi semacam ini tidaklah sempurna tanpa perwujudan penuh kesatuan hakiki dengan Tuhan. Al-Jili adalah pengikut Ibnu Arabi, gagasan ini dikembangkan menjadi bagian dari renungan mistis yang bercorak

${ }^{28}$ Ibnu_Arabi $(560 \mathrm{H} / 1165 \mathrm{M})$ adalah seorang keturunan suku Arab kuno Thai, ia dikenal di dunia Arab dengan nama Ibnu Arabi. Dua gelar yang masyhur ialahMuhyi al-Din(penghidup agama) dan al-Shaikh al-akbar(Doktor Maximus) atau guru besar. Lihat Sayyed Husein Nasr, ThalāthahHukāma Muslim, terj. (Bandung: Risalah, 1986), 127. 
tasawuf filosofis.Al-Jili merumuskan insan kamil ini dengan merujuk pada diri Nabi Muhammad SAW sebagai sebuah contoh manusia ideal. Jati diri Muhammad (al-haqiqah al-Muhammad) yang demikian tidak semata-mata dipahami dalam pengertian Muhammad SAW. sebagai utusan Tuhan, tetapi juga sebagai nur (cahaya/roh) Ilahi yang menjadi pangkal dan poros kehidupan di jagad raya ini. Nur Ilahi kemudian dikenal sebagai Nur Muhammad ${ }^{29}$ oleh kalangan sufi, disamping terdapat dalam diri Muhammad juga dipancarkan Allah SWT ke dalam diri Nabi Adam AS. Al-Jili dengan karya monumentalnya yang berjudul al-Insan al-Kamil fi Ma'rifah alAwakhir wa al-Awa'il (Manusia Sempurna dalam Konsep Pengetahuan tentang Misteri yang Pertama dan yang Terakhir)

Bagi al-Jili, manusia dapat mencapai jati diri yang sempurna melalui latihan rohani dan pendakian mistik, bersamaan dengan turunnya Yang Mutlak ke dalam bermeditasi tentang nama dan sifat-sifat Tuhan, dan pada tingkat kedua mulai mengambil bagian dalam sifat-sifat Ilahi serta mendapat kekuasaan yang luar biasa.Pada tingkat ketiga, ia melintasi daerah nama serta sifat Tuhan, masuk ke dalam suasana hakikat mutlak, dan kemudian menjadi "manusia Tuhan" atau insan kamil. Matanya menjadi mata Tuhan, kata-katanya menjadi kata-kata Tuhan, dan hidupnya menjadi hidup Tuhan (nur Muhammad). ${ }^{30}$

Muhammad Iqbal tidak setuju dengan teori para sufi seperti pemikiran al-Jili ini. Menurut dia, hal ini membunuh individualitas dan melemahkan jiwa. Iqbal memang memandang dan mengakui Nabi Muhammad SAW sebagai insan kamil, tetapi tanpa penafsiran

${ }^{29}$ Nur Muhammad dalam tasawuf merupakan makhluk yang pertama sekali diciptakan oleh Allah SWT. Dan setelah itu baru diciptakan alam yang lainnya. Nur Muhammad sering juga disebut Hakikat Muhammad atau Ruh Muhammad. Untk pertama kalinya konsep Nur Muhammad dibawa oleh sufi alHallaj. Lihat; Sahabuddin, Nur Muhammad Pintu menuju Allah, Telaah atas pemikiran Syekh Yusuf al-Nabhani (Jakarta: PT. Logos Wacana Ilmu, 2002),.36.

30 Lihat,Syed Abdul Vahid,Iqbal: His Art and Thought (Lahore:Sh.Muhammad Ashraf, 1944),103-104. 
secara mistik. Insan kamil versi Iqbal tidak lain adalah sang mukmin, yang dalam dirinya terdapat kekuatan, wawasan, perbuatan, dan kebijaksanaan. Sifat-sifat luhur ini dalam wujudnya yang tertinggi tergambar dalam akhlak Nabi SAW. Insan kamil bagi Iqbal adalah sang mukmin yang merupakan makhluk moralis, yang dianugerahi kemampuan rohani dan agamawi. Untuk menumbuhkan kekuatan dalam dirinya, sang mukmin senantiasa meresapi dan menghayati akhlak Ilahi.

Iqbal dalam The Reconstruction of Religious Thought in Islammenyebut manusia ideal dengan perfect man hood, beberapa penerjemah mengartikan istilah tersebut dengan insan kamil. Perwakilan Ilahi di dunia ini adalah bentuk perkembangan diri yang tertinggi. Insankamiladalah khalifah (wakil) Tuhan di dunia ini. Pada dirinya terjalin berbagai unsur jiwa yang kontradiktif. Unsurunsur tersebut disatukan oleh kekuatan kerja yang besar yang didukung oleh pikiran, ingatan, akal budi, imaginasi, dan temperamen yang berpadu dalam dirinya; sehingga ketidak selarasan kehidupan mental menjadi keharmonisan dalam dirinya. Dia mencintai kesulitan dalam perkembangan hidupnya, kehendaknya adalah kehendak Ilahi. Insankamil menurut versi Iqbal tidak lain adalah sang mukmin sejati yang dalam dirinya terdapat kekuatan, wawasan, perbuatan dan kebijaksanaan. Sifat-sifat luhur ini dalam wujudnya yang tertinggi tercermin dalam akhlaq nabawi.

Insankamilyang tidak lain adalah mukmin sejati, tidak memperlakukan agamanya sebagai dogma yang kikuk. Seluruh hidupnya dijalani dengan penuh semangat dan kreativitas yang sesuai dengan kehendak Tuhan. Rahasia dirinya adalah la ilaaha illallah yang mejadikannya mampu menguasai dunia. Figur insan kamil menurut Iqbal adalah diri Rasulullah Muhammad SAW yang seluruh hidup dan kehidupannya dipergunakan untuk menjalankan dan menegakkan kalimatullah, menegakkan kemanusiaan dengan penuh semangat dan kreativitas. Rasulullah Muhammad SAW telah mi'raj "ke langit" dan memperoleh pengalaman spiritual yang setinggi tingginya, namun demikian, Rasulullan Muhammad SAW 
tetap juga kembali kedunia ini. Orang kebatinan seandainya berhasil mencapai pengalaman spiritual setinggi-tingginya itu, maka dia tiada menghendaki untuk kembali dari ketenangan pengalamannya itu. Seandainya toh kembali, kembalinya itu tiada banyak berarti bagi umat manusia. Iqbal mensitir ucapan seorang sufi, yakni Abdul Qudus: "I swear by God that if I reached that paint, I should never haver returned". Rasulullah Muhammad SAW kembali ketengah kehidupan umatnya, meskipun beliau telah mencapai puncak ketenangan dari pengalaman spiritual tertinggi. Kembalinya Rasulullah adalah kreatif, yakni untuk mengawasi kekuatan sejarah dan menciptakan suatu dunia yang normal.Pandangan Iqbal tentang figur insan kamil itu sesuai dengan ayat-ayat dalam al-Qur'an surat al-anbiya ayat 107 dan surat al-ahzab ayat 21. "Dan tiadalah kami mengutusmu (Muhammad) melainkan untuk menjadi rahmat bagi semesta alam". "Sesungguhnya telah ada pada diri Rasulullah suri tauladan yang baik bagimu (yaitu) bagi orang-orang yang mengharapkan rahmat Allah dan kedatangan hari kiamat dan dia banyak menyebut Allah". Demikian cita Iqbal tentang insan kamil sebagai bentuk manusia ideal, dan merupakan tingkat kedirian tertinggi yang mungkin di capai oleh setiap diri. Insan kamil Iqbal dilatarbelakangi oleh kerinduan terhadap Tuhan dan rasa tanggung jawab sebagai wakil (khalifah) Tuhan di bumi; dan menemukan bentuknya pada diri Rasulullah Muhammad SAW.

2. Aktualisasi khudi menuju insan kamil

Insan kamil yang merupakan taraf kedirian tertinggi dan karenanya adalah tujuan setiap proses perkembangan diri, hana dapat dicapai melalui jalan tertentu dan cara tertentu pula untuk menempuh jalan itu. Iqbal berpendapat, seseorang harus melalui tiga fase untuk mencapai derajat insan kamil. Pertama, tunduk atau taat kepada hukum Tuhan. Arti penting ketaatan kepada hukum-hukum 99.

${ }^{31}$ Muhammad Iqbal, The Reconstruction of Religious Thought In Islam, 
atau aturan-aturan Tuhan dalam rangka mencapai derajat insankamil ditunjukkan oleh Iqbal dalam sebuah sajak.

"Jangan tolak beban tugas kewajiban

Agar dapat kau nikmati pemukiman

Sebaik-baiknya di samping Tuhan

Usahakanlah taat-patuh, hai orang yang ceroboh

Kemerdekaan adalah hasil paksaan

Oleh taat orang tak bernilai menjadi tinggi". ${ }^{32}$

Isi sajak Iqbal diatas adalah bahwa untuk mendapatkan sebaikbaik tempat disisi Tuhan, manusia harus mentaati kewajibankewajiban atau aturan-aturan dari Tuhan. Tuhan, dengan aturanaturan tersebut, sebenarnya menunjukkan kepada manusia jalan untuk sampai kapada-Nya. Ketaatan terhadap aturan-aturan Tuhan membuat derajat manusia menjadi lebih tinggi, karena sebenarnya dengan taat kepada aturan-aturan Tuhan manusia akan memperoleh kebebasan. Aturan-aturan Tuhan tidak membelenggu manusia, tapi justru memberi arah, dan merupakan ikatan yang membebaskan.

Kedua, menguasai diri (self control). Fase kedua yang harus dilalui dalam upaya mencapai insan kamil setelah ketaatan terhadap aturan-aturan Tuhan adalah menguasai diri atau mengendalikan diri. Hubungan fase pertama dan kedua ditunjukkan oleh Iqbal dalam sajaknya.

"Selama kau pegang kendali tiada Tuhan selain Allah

Kau akan pecahkan setiap lambang ketakutan

Seorang kepada siapa Tuhan penaka jiwa bagi badannya

Kepalanya tidak tunduk kepada kesombongan apapun

Tak ada takut dan cemas dalam dadanya

Hatinya tak gentar selain kepada Allah semata". ${ }^{33}$

Pengakuan tiada Tuhan selain Allah, merupakan esensi ketaatan. Ketaatan terhadap aturan-aturan tuhan, akan menjaga diri

\footnotetext{
${ }^{32}$ Muhammad Iqbal, Rahasia-Rahasia Pribadi, 116.

${ }^{33}$ Iqbal, Rahasia....., 117.
} 
seseorang dari sikap takut dan sombong, suatu sikap yang dapat melemahkan diri. Aktualisasi ketaatan kepada Tuhan menjadi satusatunya referensi bagi segala tindakan.Pengendalian diri menjadi penting dalam upaya mencapai insan kamil. Kenyataan menunjukkan bahwa manusia adalah diri yang bebas. Kehidupan diri manusia menunjukkan adanya dua kecenderungan yang berlawanan, kecenderungan terhadap hal-hal yang baik dan yang buruk. Kebebasan diri manusia semakin menunjang dalam memilih dua kecenderungan tersebut. Kecenderungan terhadap hal-hal yang baik berakibat semakin kuatnya diri, sedang kecenderungan terhadap halhal yang buruk akan berakibat lemahnya diri. Kecenderungan terhadap hal-hal yang buruk tidak mungkin dihilangkan sama sekali, tetapi dapat di kekang atau dikendalikan. Upaya mencapai insan kamil harus dilakukan dengan mengendalikan kecenderungan terhadap hal-hal yang buruk, dan senantiasa berpedoman kepada aturan-aturan Tuhan.

Ketiga, niyabat Ilahi atau kekhalifahan Tuhan. Seseorang yang telah taat kepada Tuhan, dan karena ketaatannya itu dia mampu mengendalikan diri, maka sampailah dia kepada fase insan kamil. Insan kamil sebagaimana telah dikemukakan di muka adalah khalifah atau wakil tuhan di bumi, yang tiada lain adalah seseorang mukmin sejati. Seorang mukmin sejati adalah seorang yang benarbenar taat kepada tuhan dan mampu mengendalikan diri. Manusia yang pantas menjadi wakil tuhan di bumi adalah manusia yang mampu membaca aturan-aturan tuhan dan mampu menafsirkan serta mewujudkan dalam prilakunya. ${ }^{34}$

\section{PENUTUP}

Filsafat Iqbal tentang insan kamil dan konsep yang berkaitan dengan bagaimana prosedur pencapaiannya merupakan konsekuensi dari rencana aktualisasi diri yang telah dibentangkan dalam filsafat khudinya. Khudi bukanlah anugerah alam, tetapi dibentuk melalui

\footnotetext{
${ }^{34}$ Iqbal, Rahasia....., 73.
} 
usaha dan kerja keras, disiplin yang tidak kenal lelah dengan keteguhan watak yang didasari oleh cinta atau ishq (keinginan mengasimilasi dan mengabsorbsi sifat-sifat utama dari yang dikasihi), faqr atau keteguhan sikap (upaya untuk meraih sukses), keberanian dan kreatifitan.Proses insan kamil tidak terjadi dengan begitu saja tapi harus dilakukan dengan bersungguh-sungguh, mengikuti secara teliti dan tekun kehidupan nabawi, melalui tiga tahap, yaitu ketaatan kepada hukum Tuhan, pengendalian diri sebagai bentuk tertinggi kesadaran diri tentang pribadi dan kekhalifahan Tuhan. Ketiga tahap tersebut tidak berjenjang satu demi satu tetapi saling merangkum.

\section{DAFTAR PUSTAKA}

Adian, Doni Gahral. 2003 Muhammad Iqbal, Bandung: Teraju

Ali, Mukti. 1993 Alam Pikiran Islam Modern di India dan Pakistan, Bandung: mizan

Azam, Abdul Wahab.1985 Muhammad Iqbalsiratuhu wa falsafatuhu wa sha'ruhu, terj. Rafik Usman. Jakarta: pustaka

Hamersma. 1984.Tokoh-tokoh Filsafat Barat Modern.Jakarta: PT. Gramedia.

Iqbal, Muhammad. 1986 The Reconstruction of Religious Thought In Islam,Lahore:institute of Islamic culture.

Khan, Asif Iqbal. 2002 Agama, Filsafat, Seni Dalam Pemikiran Iqbal, terj. Farida Arini, Yogyakarta: fajar pustaka baru.

Lee, Robert D. 2000Mencari Islam Autentik Dari Nalar Puitis Iqbal Hingga Nalar Kritis Arkoun, Bandung: mizan.

Lidinillah, Mustofa Anshori.2005 Agama dan Aktualisasi Diri Perspektif Filsafat Muhammad Iqbal, Yogyakarta: badan penerbit filsafat UGM

Mu'awwiḍ, Ahmad. 1980Muhammad IqbalHayatihi wa Atharihi, TT. 
Rusdin, Insan Kamil dalam Perspektif Muhammad Iqbal...271

Nasr, Sayyed Husein.1986 Thalathah Hukama Muslim. terj. Bandung: Risalah.

Poedjawijatna, I.R. 2005.Pembimbing ke Arah Alam Filsafat. Jakarta:Rineka Cipta.

Rahardjo, M.Dawam.1987.Insan Kamil, Konsepsi Manusia Menurut Islam Jakarta: Pustaka Grafitipers.

Sahabuddin. 2002 Nur Muhammad Pintu menuju Allah, Telaah atas pemikiran Syekh Yusuf al-Nabhani. Jakarta: PT. Logos Wacana Ilmu

Saiyidain. K.G. 1981. "Iqbal Education Filosofi” Percikan Filsafat Iqbal tentang Pendidikan, terj: MI sulaiman Bandung CV. Diponegoro

Schimmel, Annemarie. 2001"And Muhammad is His Messenger; TheVenerationof the Prophet in Islamic Piety" terj. Rahmani Astuti dan Ilyas Hasan,Dan Muhammad adalah Utusan Allah ,Penghormatan terhadap Nabi SAW. Dalam Islam ,cet.Vlll .Bandung: Mizan

Soleh, Khudori. 2004 Wacana Baru Filsafat Islam, Yogyakarta: pustaka belajar. 